\title{
필 (1) \\ Social and solidar economy in french point of view
}

\author{
Yves Coutand \\ Institut Régional du Travail Social, Poitiers, France
}

DOI: $10.19055 / \mathrm{ams} .2013 .4 / 8-9 / 4$

\section{Introduction}

Let me introduce myself, I am working in the Regional Institute of Social Work Poitou-Charentes in the city of Poitiers in the department of Vienne in France. Saying that, I have identified the four levels of the administrative and politic organization of France which is well known to be rather centralized.

- The national level: France,

- The regional level: Poitou-Charentes,

- The departmental level: La Vienne, our region is composed of four departments,

- And the municipal level: The city of Poitiers.

I'm here invited by your university and Mr Fabian, dean of the Faculty of Sociology and as a member of the SOWOSEC network. This adventure started six years ago between eight European universities to create and implement an European Master in Social Work and Social Economy I should be there with Mrs.Martin Papineau, our partner of the University of Poitiers, director of the Master, because, maybe you do not know, the training courses in social work in France are not included in the University, they are provided by professional associations, private institutes, providing public service missions to prepare students in social work to national degrees. These missions are funded partly by Regions since the second step of decentralization, the rest of the activity is financed by selling own training products to the public or private institutions involved in the field of social work Describing 
this situation, I am also pointing our business organisation as an actor in the social economy sector, a little without knowing it, or realizing it was a business not quite like the others,.I mean that economic activity had primarily a social purpose. This does not prevent it from going on to deplete its managerial exercise of control of costs of finding new markets in a logical where tenders of new public are creating a new competitive environment that sometimes put at risk the quality of the service provided.

The dilemma or the tension between these two poles of economic and social is the basis of the social economy movement in France or to be more precise we should say that the invention of social, in the the second half of the nineteenth century, tried to solve the tension between the economics and politics opened by the French Revolution. The young republic had set up the sovereignty of the people and, in the night of August 1789, abolished privileges of the dominant orders, aristocracy and clergy, but she had not realy successed in satisfying concretely the waitings of this sovereign people to gain access to work, social security and justice.

I wanted to make this preamble because we can not, in any case it is not possible in France, when we are looking at this new interest for the social economy in the context of crisis of the dominant economy, to ignore this social imaginary based on undeniable historical foundations As the African proverb say, "If you do not know where you are going, look at where you are coming from".

From the third State to the third sector connected we will see, in a globalized economy, with the third world, the history of social economy is also the story of the ongoing effort of the "voiceless" to make themselves visible and to find answers and practical solutions to everyday problems, economic, cultural and social, that political institutions can not (or will not?) solve. Doing that, through their participation, they bring to democracy the link to reality, a food for thought, an openness to democratic representation system that could not stand on by its own.

So my presentation will follow this plan. Social and solidar economy a concept to be understood, and activities to get more visible.

- Social and solidar economy in an historical perspective.

- Definitions, differences and similarities.

- Fields of activities.

- Social and solidar economy toward a blended and embeded economy.

- Panorama of social economy in France.

- Social economy, opportunities and challenges. A new alternative?

\section{Social and Solidar Economy, concept a little bit fuzzy at the European level}

To come and talk about the social and solidar economy here,at the other end of Europe, supposes a quick look at the diversity of practices, statuts and concepts at a european level. Five years of collaboration within the network have already 
revealed differences and perhaps oppositions in any case possible areas of misunderstanding that may exist between national concepts of social economy within the EU and that probably not facilitates its recognition within the European institutions I repeat here the remarks of Laura Lepetre member of European think tank "For solidarity".

"Addressing the social economy sector across the European Union is not a simple matter. Debates and disagreements around a common definition, the differentiation of perception of the concept in member countries do not facilitate an overview of the sector and an unified advocacy. Indeed, various contradictions and visions come to blur the perception of the sector by policy makers and not conducive to social economy credibility. ${ }^{1}$

I will not repeat the work of Mrs.Gruber, our leader within the network who has spoken just before but I wanted to mention the report prepared by the International CIRIEC for the European Economic and Social Council 2005.

By interviewing three groups of stakeholders :public authorities, enterprises in the social economy and members of the academic and scientific, on the degree of knowledge and recognition of the concept of social economy, researchers identified three groups of countries according to the degree of recognition and acceptance of the concept of social economy I tried to represent it within three co-centric circles from more recognized to least recognized.

If we apply the same exercise to the concept of solidar economy we could stay in the first circle, and yet not all members: France, Spain, Portugal, Italy, to a certain extent : Belgium and Luxembourg and, in a sense limited to business projects and people having difficulties to integrate the labor market: Sweden, Finland, Poland.

This concept of solidar economy, invented by two French sociologists Bernard Eme and Jean Louis Laville in the 1980s, has got a good recognition in South America (Brazil, Argentina, Peru ...) and of course has a similar approach to participative democracy like developed for example around the city of Porto Alegre.

At the European level, there are other overlapping concepts as third sector, non-profit organization and the latest, whose definition also remains controversial, as social business or social entrepreneurship

"The recent European Commission communication on social entrepreneurship, including social entrepreneurship initiative of 25 October 2011, is a big step forward. The Commission recognizes the importance of the sector and provides tools to foster its development. But do not be mistaken, when these communications must be transformed into a regulatory framework, progress is very slow and extremely difficult for institutions to legislate on the issue .... In addition, actors are confronted with a recovery of the concept by the advocates of "Social business," more liberal view of social enterprise, distorting the foundations of the cooperative and mutualist sector. ${ }^{\prime 2}$

\footnotetext{
${ }^{1}$ L'économie sociale : l'alternative face aux crises. Prospective et recommandations pour un plaidoyer dans les politiques européennes. Laura Lepretre working paper Septembre 2012.

2 ibid
} 
It is now time to clear what kind of philosophy the concepts of social economy and solidar economy in France are covering, to clarify their differences and identify their oppositions or their similarities and also, starting from 2000 years, to try to understand the convergences which make that, despite some tensions, it is possible now to speak of social and solidar economy without causing kneejerk reactions on either side.

As you can see we preferred the synthesis to the rejection of any design. Do not throw anything, this may be an early form of sustainable development.

\section{The historical origins of the social economy}

It would be of course totally unrealistic to try again here to describe in a few words the richness and diversity of the history ,sometimes tragic, of social movements in nineteenth centuries. It is in this crucible that have been forged the great ideologies, Liberalism and Marxism, that have been presiding over the destiny of the twentieth century, on which I do not intend to dwell either.

However, we must go back to this episode of the story to understand the emergence, between opposite poles mentioned above, of a "third way" in the context of development of industrial capitalism, completely unbridled, and social disorder caused by rapid urbanization around major industrial and commercial centers.

Inherited the spirit of corporations, guilds, that the law "Le Chapelier" had abolished in 1791, workers' associations have grown steadily since the beginning of the nineteenth century, mostly in a clandestine way, in order to fight against the bad living and working conditions that unlimited economic liberalism imposed to them, both in the companies and in the public life, and to call on the democratic state on its lack of intervention.

In the context of development of the industrial revolution and dramatization of the social question, the lesson of St Simon is severe ::"The economic facts void the politics " "Political economy, a science of the wealth of nations which are starving" Considerant Victor (1808-1893).

"Democracy in the political and the almost absolute monarchy in the workshop are two facts that can not coexist longer " Anthime Corbon " The Workshop" 1849.

Neither the declaration of human rights or political democracy are sufficient by themselves, the Issue of poverty and of exploitation of the workers is thus inseparable from a more general question:

"How now reconstruct society on new bases, reinventing forms of solidarity that are neither organic (traditional) or purely individualistic and contractual... Fraternal societies, associations of free workers. From this crucible of popular initiatives will be born ,fast enough, unions and the status of organizations that theorists call the social economy .... 1848 is the first moment of meeting, prepared since 1830, between the working class, the first socialist theorists and the Republic "/Chanial Laville, 2000]. 


\section{Different ways of thinking social economy}

St. Simon, Fourier, Proudhon, Louis Blanc, these popular initiatives have inspired and been inspired by many thinkers of the time, but they have also inspired politicians, republican leaders, economists (Gide), philanthropists or religious (Buchez, Raiffeisen), secular, revolutionary, radicals or moderates. (Schulze Delitzsch).

They can be grouped around four major schools of thought (see slide), we should add one fifth with the utopian socialists (Fourier Godin).

"Whatever the diversity of approaches they have two characteristics.

The voluntary, religious or secular, is rooted in a claimed belonging to a community strengthened by the implementation of an economic activity.

The action is part of the construction of a democratic society and is involved in public space.

We shall keep in mind

4 keywords: Volunteer, autonomy, equality, solidarity.

Two principles:

- "Act here and now."

- Shared responsibility (for both (the affiliates and disaffiliated).

3 statuses will emerge gradually

Cooperatives (1867), Mutuals (1898), Associations (1901).

In the history of the labor movement, it is finaly the option of marxist collectivism which prevail among the workers, and they will separate the reformist branch, accusing the cooperatives of production of gentrification as it hire not associated employees or refuse new members.

"The disconnect between the labor movement and the cooperative movement is probably rooted in the law of 1884 (Law Waldeck Rousseau) that recognizes freedom of association, but by restricting trade unions in the defense of workers, prohibiting them to manage directly economic activities (unlike their German counterparts)." 3

\section{To the welfare state: the institutionalization of Social Economy}

During the second half of the nineteenth century, extending the associationist mouvement, the struggles lead to compromises legalizing the existence of organizations with different legal statuses in which a group of agents, other than investors, get the status of beneficiaries These organisations will gradually be defined as social economy organizations. Social economy is therefore seen as a sector including the statutes of cooperatives, mutuals, associations, where it is not the constraint of non profit that is important but the fact that the material interests of capital providers is subject to limits.

\footnotetext{
${ }^{3} \ll$ Histoire de la coopération professionnelle $\gg$ coop.fr
} 
"The French approach of social economy is distinguished from the English approach of the nonprofit sector by connecting these statutes which are considered part of the same associationist genesis, and to which should be attached also the unions. In the French design, the border is not therefore between organizations with or without profit, but between capitalist societies and social economy organizations that prioritize the settlement of a collective heritage more than the individual return on investment, restrict private ownership results. The approach of the social economy values this recognition, but in doing so, it obscures the entry in an institutional architecture based on the separation between "economy" defined as a market and "social" defined as under the state responsibility. "[Chanial Laville, 2000]

Moreover, concomitantly, the notion of solidarity knows some inflections. After the trauma of 1848 ,when workers'initiatives are repressed, it is at the end of the nineteenth century that the concept of solidarity is seen, for Republicans, as a way to reconcile individual rights and state responsibility.

"Defended by politicians, lawyers and sociologists who call themselves solidarists (Bouglé Bourgeois, Duguit, Durkheim ...), the notion of solidarity takes on a new meaning. More than common participation to humanity, as in the previous period, the solidarists talk about social debt toward past generations, which men are liable, and toward future generations. That implies a quasi-contract " a legal form of the dual social debt corresponding to the duty of solidarity with our fellows and our descendants" [Dubois, 1985]

"The search for balance between freedom and equality is built by dissociation and complementarity between economic and social and finds its expression in the idea of public service linked to the notion of solidarity" [Laville, 2000]

The State, expression of the general will , becomes custodian of general interest implemented through administrative action. The administration, which gets its legitimacy from the political representation as the company gets its legitimacy from the capital, can not see the user in another way than a subjugated .Benefits are assigned in a top down mouvment from the State, only representative of the general interest, to the recipient citizen. The legitimacy of state intervention is limited by social solidarity, but it reinforces its "colonial power" and "its central role in shaping society".

Based on law, state intervention is a pragmatic adaptation of the theories of social cohesion trying to avoid the twin dangers of "individualism" and "collectivism".

"In this case, the associationist mouvement which had been the first reaction of the community against disturbances caused by the diffusion of market gradually gives the way to state intervention. "[Laville, 2000] The social question leads to the separation of economic, in its acceptance of market economy, and social, legal way to protect the society, developped from the division of labour in the two related registers of labor law and social protection. 
In this context social work, that had in associationism common origins, will unfold and gradually professionalize its intervention. Doing so, gradually leaving economic issues outside its activities, it deviates from the social economy project focused on emancipation, and takes the role of reparation when it is not of education of the poors, limiting its action in the register of duties assigned by state, either directly or by delegation of public service, subject to the redistribution of subsidies so called now "social assistance" by differentiation of "social insurance" due to the redistribution of income transfers related to work.

Issue of work or non-work becomes the discriminant criterion and prefigures the emergence of the category of the disaffiliated, the excluded.

As long as the welfare state may, by its regulation of the economy now desembeded from the other rules of the social game, ensure its solidarity with the most vulnerable and the poorest, social workers can focus on these populations (disabled people, children at risk, elderly people ) to help them to come back in the great game of consumption and do their job with the illusion of an autonomous social field. But, as soon as the first signs of weakness of the system appear, they will feel helpless in front of the emergence of this new class of poor, excluded from work, waiting again for the train of progress, but this time without knowing neither the platform nor the timetable ...

\section{The welfare state and the thirty glorious years}

The post-war years until the first oil shock are marked by strong economic growth and, in this virtuous context, this period, described by Jean Fourastier as the "30 glorious years", is marked by numerous social progress (labor law, social security, family allowances). The couple State / Market regulated through social dialogue with trade unions installs a majority of French people in the society of mass consumption inspired by the Fordist model.

In this context, social economy organizations take their share in a totally integrated way, developing themselsves in this regulated market either in the field of production, consumption and finance where cooperatives and mutuals adopt a competitive and classics business development, or in the field of protection and insurance where they complement the action of State. Associations, supported by subsidies from the state when their action is on public service missions, multiply in the field of culture, popular education, social action towards the children and youth protection, poor families, disabled people and later elderly people. They finaly relate in one way or another (consumer, finance, insurance, education, social protection) all French citizen without these one have the feeling of having to deal with an "other economy".

Doing that, these organisations, with special status, all focused on improving the satisfaction of needs in a context of widespread consumption way of life are finaly blended with the rest of the market system as in the production of their service or their way of management. 


\section{The trivialization of the social economy}

This phenomenon of invisibility is the result of a process called institutional isomorphism, it has been theorized and defined as follows "A cumbersome process that forces units in a population to look like other units that face the same set of environmental conditions" (DiMaggio, 1983 Powell, 1991).

Three factors of convergence - isomorphism - are observed:

- Normative isomorphism : the professionalization of the workforce, through the standardization of educational networks and recruitment criteria;

- Mimetic isomorphism: in a context of uncertainty and bounded rationality, organizations tend to imitate each other (a phenomenon also observed in finance, under the term "herding" or "herd behavior").

- Coercive isomorphism: the pressure exerted by the State, including through public funding, may ultimately impose certain behaviors, thereby taking into account common standards.

Conclusion

If the Thirty Glorious gave the feeling of a phase ideal-typical in terms of solidarity, they have also defined this historical period in which western societies have learned to overcome the tragedy of the second world war by engaging in a rush to consumption, which has not stopped since the begining .

"Even more than in the past, suddenly everything was located on the needs in the absence of clear boundaries between what was within the scope of actual needs and what does not fall within. The reason is probably due to the fact that the world conflict had created a deep spiritual and material abyss, necessary to fill. But that abyss is, in turn, coupled with an inability to formulate an "ideal of the good life" (Ricoeur, 1990) which can not be reduced to this single question, thereby creating a situation marked by the incessant production of new needs, including that, this economic operation maintained the illusion that they were absolutely necessary and should be filled without delay. " [De Nanteuil 2008]

This has been traduced for the organizations of the social economy by a trivializing of their activities in the market system (same middle class customers, same products, same prices, same funding, same management) and a loss of its visibility.

\section{Alternatives Résurgences and neo capitalism}

Even before the two oil shocks bring the crisis of the 1980s ( rising insecurity and unemployment, industrial restructuration, liberalization, globalization and virtualization of the economy) that we never really left, the french society knows in the early $60 \mathrm{~s}$, as in other economically developed western countries, what some have called a silent "cultural"revolution whose point of emergence in France will be the 1968 movement. This is probably, as suggested Montesquieu, when institutions are more strong (more achieved), they begin to waver. Could this be the moment 
of entropy described by systems theory ? At the same time (1969) the Club of Rome launch its inaugural alert : "Stop growth" ecological critical analysis of our development model.

Started in the student circles, the sling will spread to the world of workers and, despite media still fairly controlled by the state (ORTF), to the whole of society.

Since the 1960s, changes in lifestyles introduce in discursive aspects of social behavior that were formerly intangible or settled by traditional practices" [Giddens, 1994, p. 120].

For workers, consumers or public services users, the lack of opportunity for involvement has been criticized as well as the standardized approach of the request to supply mass goods and services very stereotyped.

Appears the requirement for a higher "quality" of life. To the quantitative growth is increasingly opposed the demand for qualitative growth," a lifestyle policy has to be substituted to a standard level of life policy " [Roustang, 1987], It is time to take into account the dimensions of participation in different areas of social life, to preserve the environment, to change relationship between genders and ages. This criticism is partly expressed through new social movements like feminism and ecology. At the same time, voices are rising to question the ability of government intervention to correct market failures. Users denounce bureaucratic and centralizing logic of institutions: For them, the lack of ability to innovation generates inertia, social control and patronage. Worse, inadequate public response to differentiated situations of life explains the survival of inequalities behind an apparent leveling standardization.

\section{Solidar Economy}

In this effervescent context will emerge forms of alternative economy foreshadowing the solidarity economy. Between 1960 and 1982 the number of associations explodes (from 12000 to -40000) We could actually break the period from the year 1968 to the present year in three times. To do this we follow the periodization proposed by Benoit Levesque (2002). Questioning the relationship between social innovation and social enterprise, he recalled in the introduction that :

- "social economy is by definition innovative because it usually try to meet the needs or expectations not met by the market or the state.

- the" new capitalism " call more and more social innovation to face the challenge of increased competition by opening markets and in order to benefit fully from the potential of new technologies. " [Boltansky Chapiello 1999]

A first period, 1968-1975, when, in the wake of the new cultural movement, experimentations and social innovations are designed by a new educated class (which some call the new middle class) who puts forward new values ( rejection of mass consumption) and self experiences (denial of monotonous work, authoritarian forms of management). Social innovations are intended to be in opposition to the domi- 
nant model of consumption and mass production. They want to work otherwise (labor crisis)and/or even live differently....

It is time to break with the traditional way of fighting, "the order to disperse," the invention of new methods of green living in the countryside (neo rural movement), the exaltation of local " live and work in the native country " and experimenting with self-managed human sized enterprise "small is beautiful".

"If the majority of communities after the May 68 movement was probably too radical alternative to live sustainably, they found their continuation in an alternative economy which refers to the creative utopia and claims the possibility of "another way" development based on self-management, solidarity and autonomy". In the words of Philippe Outrequin Anne Potter and Patrice Savage. "This alternative economy questions all social and economic institutions: the company and its organization, the market, the state." [Levesque 2001]

Federated within the Liaison Agency for the development of an alternative economy, ALDEA, this alternative economy has paved the way for solidar savings with investors clubs for hedge funds and local and solidar savings (Cigales).Heralding new forms of organization, it unifies the movement of reciprocal exchange of knowledge (RERS), then the movement of local exchange systems (SEL). One of the major current areas of french economic alternative is made by the Network of alternative and solidar practice (REPAS).

In terms of socio-economic innovations, we willingly says that the social economy is often the spur of the state and the market. We can also say that the "alternative economy" is often a spur of the"social economy".

Ethos of this "alternative" economy is not without some influence on the historical structures of the social economy (cooperatives,mutuals, associations) in particular in its third component, associations. Grouped within the CNLAMCA born in 1970 and under the leadership of critical intellectuals and researchers such as Henri Desroche these historical entities are faced with the same effervescence protest of its members and begin to feel the need to reaffirm their fundamental values, the specificity of their collective enterprises. In the 80s, the CNALCMA offers its members a charter in which are intersecting democratic, legal, humanistic and redistribution requirements . The following year (1982) with a decree suggested by the politician Michel Rocard (very impressed by the work of Desroche) is created the Interministerial Delegation for Social Economy DIES (1983), Institute for the development of social economy.

However, according to Daniele Desmoustier conclusions, the CNLAMCA had neither met the self-management movement of the 1970 or directly supported the new social problems engendered by socio-economic changes (2000). All this tends to give credence to the hypothesis that ALDEA is born from a lack of structures of the social economy.

According to Bruno Frere, this gap between solidar economy and social economy is not really ideological. Desroche or alternative claim to the same Proudhonist 
associative origins, it is empirical, just a question of size. But the evaluation of Daniele Desmoustier is more severe:

"The SCOP were powerless to take over bankrupt firms and reintegrate unemployed workers, health and social associations have outsourced the function of youth integration, cooperative banks have left to solidar organizations of financing the responsability to care and reveal the needs of small-scale projects, agricultural cooperatives have abandoned rural development. "4

In the second period, 1975-1985, innovations are less coming under the criticism of dominant model in altenative aspirations than from needs created by the crisis in the coordination and control between state and market, the breakdown of the virtuous circle:( economic development / social development), through state redistribution and support of demand.

Two streams of social innovation are identified by B Levesque:

The first one is less to respond to the labor crisis (refusal of monotonous work) than the employment crisis. Arise then social innovations in the field of job creation and economic development (implementation of sheltered workshops in the mid-1970s, construction of tools for integration through economic activity from 1974 ).

The second stream then: as much as a denial of bureaucratic functioning than due to the lack of State initiatives for new social demands, social innovations emerge in the field of social development, housing, services to persons. (local social development, neighborhood governed outreach, parental managed creches ....)

Difficult but fruitfull in terms of social innovations; these experiences then take the form of pilot experiences and are weakly institutionalized. At the crossroads of these initiatives in a sometimes contentious relationship with the public, the new neighbour public space is built, whose main actors gradually will claim solidar economy.

If we are trying to define in a few words that solidar economy: we shall remind

- 4 concepts: participative democracy, local public space, social utility and social responsibility, sustainable development.

- 2 articulated principles: Think globally, act locally for a logic of communication and action included in contemporary forms of networks, in partnership with other stakeholders: local authorities, pubilc administrations , private sector, and in a global solidarity.

- Under statutes borrowing from historical models of cooperatives and associations and progressively integrating foundations.

\footnotetext{
${ }^{4}$ In Frere Bruno, Le nouvel esprit solidaire, Desclée de Brouwer,2009.
} 


\section{Social Economy and Solidar Economy}

Between a social economy up to date, exhumed from its foundations by Henri Desroches in 1977 and a solidar economy reinvented by its actors and conceptualized by Jean Louis Laville and Bernard Eme in 1980, what links may we find, what similarities, shared values, what differences, potential disagreements? Finally what connexions are tempted between these two components to offer what some call an alternative to the dominant market economy, a new "steam" to the economy controlled by the state?

Firstly it must be admitted that no scientific definition can be proposed, to unify a set of practices with a common history rooted in mutual and associationist practices of the labor movements in the XIXth . These practices were relayed, reinforced and most often diverted from their original use by philanthropic members of the middle class who tried to anchor them in the activities of a third sector repairing the injustices of the capitalist system, and compensating the weak regulation of state In the idea of François Espagne, inspired by the research of Daniele Desmoustier, the term social and solidar economy would be only a syntagm, covering a range of practices, and searching a paradigm of unified significations.

On the one hand a set of organizations with specific status: cooperatives, mutuals and associations operating in the field of production, consumption and finance for the cooperatives in the insurance, health and social protection for the mutuals, in the social action, cultural and popular education for the associations.

On the other hand a set of citizen initiatives to democratize the economy, reintroducing values of autonomy of fairness and justice in trade both on a local level ( neighbourhood democracy, regies de quartier ) and international level (fair trade) with a growing concern for environmental protection and sustainable development (eg organic agriculture and AMAP).

If we try to compare term by term these two concepts of economy what do we find?

- A common history which both claim to come from, based on the values of empowerment and solidarity. But it is a solidarity that does not take only the cold and mechanical aspect of a system for redistribution of incomes by state, but a hot, organic solidarity ( of the community ) daily expressed between its members by shared values, common conditions and / or common territory with in addition a solidarity between generations in preserving the common inheritance of the nature.

- Common statutes, found in both, the associative form being the most common and in a lesser extent the cooperative.

- A more controversial concern for the collective interest and/or general interest. This distinction is often put forward by the actors of the solidar economy, more focused on democracy and general interest, to differentiate themselves from the social economy more directly focused on the collective interests of its members (ingroup versus outgroup).

- Practices to respond to social needs in an alternative way to the mar- 
ket economy (balance of selfish interests) or state intervention (assistantship). We can find these practices in the origin of the social economy, but its fragmentation into different statuses, its institutionalization in the dominant productivist model made this singularity invisible. The solidar economy has been coming to criticize the drift,reactivate this historical dimension of solidarity, renewing emphasis on an other way to invest the economic field.

- By pooling the contributions of everyone around a common project discussed democratically.

- When not using the product of the activity, the profit, to remunerate the capital but by using it to serve the activity, or by limiting the compensation of its members, as partners in cooperatives.

- By putting the business activity in the service of general interest (social utility, sustainable development) using, to do this, the internal and external solidarities either for finance (cigales) or work (volunteering).

- Reinventing solidarity on a territory (district management, AMAP, local currency) and other forms of non-market exchanges ( SEL, knowledge exchange network)

\section{Panorama of SSE}

Produced by the national observatory of social economy, the "Panorama of SSE in France and in the regions" now provides regular synthetic light on the specificities and the weight of this socioeconomic set.which represents in 2012 more than $10 \%$ of employment in France.

"The social economy brings structures that are defined as groups of people rather than capital, bearing a community project. They aim to implement innovative projects that combine community service and economic activities. To meet the needs, unmet or poorly met, of populations and territories, contribute to local development, sustainable and inclusive, are goals that take precedence over the search for financial gain. ${ }^{\prime 5}$

With 222900 employer companies clustered around statutes of cooperatives, mutual societies, associations and foundations and $\mathbf{2 . 3 4}$ million employees, the social economy represents nearly $14 \%$ of private employment.

If we consider the impact of their activity on the entire population, 19 million French people join a health insurance, nearly 22 million are members of a cooperative bank, 21.1 million are members of a mutual insurance company, between 11 and 16 million volunteers join associations (NPO). More than 1 out of 4 french citizen is a member of an association.

However, the French citizen who join an organization or company of social economy ignore it sometimes and do not systematically exercise the rights and duties granted to them by their quality membership in their association, cooperative or

\footnotetext{
${ }^{5}$ Panorama de l'économie sociale et solidaire en France et dans le régions,CNCRES 2010 et 2012.
} 
mutual. But it is a central issue for the project of the organization to be aligned with the needs of its members.

\section{In search of the lost paradigm}

We have seen from this descriptions before, social and solidar economy involves modes of regulation more complex than those one obeying the simple rules of the market.

It recall ,following Marcel Mauss, Karl Polanyi and Fernand Braudel, that economy based on the exchange is not limited to the single modality of liberal market economy. But beside the market or public economy existes another form of exchange, as old as the human history, the economy of reciprocity, as it is with the gift or the invention of a local currency or exchange of non-monetary services rooted in the domestic or nearby economy.

In a word, the economy of reciprocity, forgotten by all our representations imbued with individualistic philosophy, takes the abstract individual off his selfish acts and puts human at the center of its concerns by including him in the network of social relations.

"To report imperialist states we have no problem In the idea of most of us, the expansionist principle is rarely a democratic criterion. Why then do we resist so vigorously to denounce the whole individual powerness? Why do not we consider a democrat is someone who knows precisely limit his omnipotence? "6

Lost paradigm is that : an economy that has always been diverse and of which shapes borrow to the three raised components, one is the market that , while promoting the rational calculation of competition, stimulates innovation, other is the public economy concerned in regulating principle of equality and justice and third is home economics full of fraternity solidarity and donation.

As Jean Louis Laville remembers, there are now two distinct approaches: social economy and solidar economy, of which complementarity is still largely to build to achieve a social and solidar economy unitarian in its diversity.

But social economy as solidar economy only make sense in relation to a plural economy, that is to say an economy that does not reduce itself to the capital corporation and the market, in which several economic logics can be developped . It is by emphasizing cooperations on concrete projects between social economy and solidar economy, confirming the positive changes in the relations with public authorities, to the research and to social movements, that it is conceivable to achieve a saving strategy for social solidar economy.

"An essential principle, widely shared between the two economies, is the research and claim for consistency between words and deeds ... In any case, it is assumed

\footnotetext{
${ }^{6}$ Cynthia Fleury, "Les pathologies de la démocratie." P124 biblio essa.
} 
that the confrontation of values to practices avoids both to reduce values to artifact, on the one hand, and to be confined in the area of practical technics, on the other hand. This confrontation can raise each other to the status of policy. "[Laville in RECMA]

Thus, by the conquest of social rights and duties of everyone with access to membership, ie to the dual economic and political quality, in the company as in SCOP, social economy is an extension of solidar economy. And solidar economy, meeting the general interest wherever the universal rights of the person are in question, is a force of generalization or regeneration of the social economy.

"Without the solidar economy, social economy risks becoming a corporatist economy. Or dealing in the margins, without social economy, solidar economy may be just a economy of poors repairing the damages of the capitalist economy. In both cases, they may reach one and the other the opposite of the empowerment they both aim."

\section{Social and Solidar Economy and Territory: towards a plural economy}

Between the micro level of the firm or of domestic economy and the macro level of a global economy, between the small local initiatives taken by associations in solidar economy and the powerfull firms of social economy, what is the relevant space to cooperate and implement their values, to promote development of this new paradigm of plural economy?

Again, without seeing historical determinism, looking back should allow us to clarify this question. From the year 1970 we could say that we are witnessing, at the national level, a kind of crisis of centrality: under the influence of various processes. "The French model of centralized intervention from the state through sectorial policies gave signs of freezing" as it has been analyzed by sociologists of organizations such as Crozier and E. Friedberg. ${ }^{8}$. What we could quickly call the sectoriality crisis of the welfare state, directly hit by the new economic situation , is then going with a dual centrifugal movement of decision centers and executive frames. ${ }^{9}$

- Towards the supranational: economic globalization and European integration.

- Towards sub-national: in a more local level, as an attempt to re-appropriation by the politics of a physical and social space increasingly subject only to the logic of economic flows, making the territory without any "quality" or identity.

This attempt to re-appropriation, supposed to reduce the tension between economic logic and citizenship logic, is primarily reflected in France by the decentrali-

\footnotetext{
${ }^{7}$ Draperie Jean François, Au bénéfice de la crise Pour un projet d'économie sociale et solidaire RECMA No. 330.

${ }^{8}$ M. Crozier : "Le phénomene bureaucratique", Seuil, 1963.

${ }^{9}$ P. Muller : "Les politiques publiques", PUF, 2000.
} 
zation law of 1982-1983 in which social action policy was one of the field the most ostensibly achieved.

This redeployment of social intervention field, this territorial come back is also added to "new methods of intervention, more transverse, inter-institutional, with partnership, in response to the complexity of the issues raised by the rise of social insecurity. The corollary of this process is of course the emergence in the field of intervention of new powers, new devices, new actors whose entanglement of missions and modes of intervention questionned, shaked occasionally, knowledges and classic competences of social workers." (Coutand 2004)

"How can we understand the system of tensions which, we have seen, cross all the aspects of the territorialisation of policies? Saying it is a clash between a market logic and a logic of citizenship or more broadly between control of the territory by economic rationality or political reasons. $" 10$

So is born a complex paradox between globalization of the economy, in this case the territorialisation can be seen as a set of reshaping of the contradiction between capital and labor in a logic of internationalization, and localization of the policies.as an attempt by politics to reappropriate the organization of the territory became without any quality.

Subjected to the logic of flows, the territory is fragmented. On the one hand, the economic territory: made of flux, mobility, flexibility, exchange, circulation, short time profit, speed, instrumental treatment of space and on the other hand the political territory made of fixity, tradition, history, identity, long time, symbolic treatment of space.

For thirty years, social and territorial inequalities have widened, one reinforcing the other.The disturbances, affecting a number of rural and urban areas, has redefined the bases of identity and solidarity. Traditional forms of solidarity as professional solidarity (among farmers, workers, between teachers ...) are threatened.

Territorial solidarities emerge and show the way to new complementarities, build new forms of social and economic development through the mobilization of human, financial, cognitive ressources ... and the definition of transversal projects territories. "The role of social economy on the development of territories then goes in three directions: the participation to local development instead of traditional state planning the restructuring of organizations to face this new functions of the territories, particularly in urban areas, the construction of new partnership. "11

In conclusion the social economy emerging on territories under the impulse of necessity, is a plural economy insofar as it is able to mobilize resources from the market from the redistribution by state,and from the reciprocity or the gift from individuals or groups within civil society (market, non-market, currency and noncurrency).

\footnotetext{
${ }^{10}$ Autès M., Le sens du territoire, Recherches et Prévisions, No. 39, 1995.

${ }^{11}$ Artis Amélie, Demoustier Daniele et Puissant Emmanuelle, Le rôle de l'économie sociale et solidaire dans les territoires:, six études de cas comparées, RECMA No. 314
} 


\section{From local to global toward an alternative}

If the 1980s can be characterized as the end of an era, the 1990's are the beginning of a third period, not of crisis but a period of change where we are witnessing the beginning of a reconfiguration of the state, the emergence of new forms of regulation, new forms of coordination and new modes of governance.

"In this context of change, social innovations are no longer at the margin as in alternative culture of the years 1968-1975. Social innovations are now stakeholding in the emergence of a new configuration of capitalism of which contours remain moving according to the different levels of analysis "[Levesque]

- At the level of social actors, new actors appear, including civil society, NGOs, indigenous peoples, women's groups, etc..;

- At the level of the political system emerges reconfiguration of power between nation-states, global and continental bodies, local and regional authorities;

- At the level of organizations are invented new forms of coordination and governance (stakeholders and civil society), not only redefining the relationship between social and economic but also the meaning of social and economy.

In the 70s, the weakening of top down processes in public policies has fueled bottom up claims of local democracy and endogenous development, which led to a revival of territorialized mobilizations through a double process: the emergence of very small organizations inserted into their neighborhoud, and the decentralization of big organizations seeking to reach out to their members.

It is also at the regional level that will gradually assert new forms of coordination in the social economy (regional chambers of social economy with cooperatives, mutuals and associations). But instances of coordination also arise at a more local level, such as local committees of the social economy, solidarity economy homes. Then it is up to create representative bodies to discuss with public authorities, for delegation of public services, including ESF measures, but also to coordinate partnership actions between organizations.

"The social economy is indeed trying to build an economy based on human values by the reintroduction of solidarity in the economic functioning: So we rediscover that the field of economic can collectively be thought and built ( which means that the economics is subject to a collective decision, so as the politics ). Solidarity implemented in the context of the social and solidar economy is in a framework of réciprocity, so it is empowering, as opposed to any charitable approach, in essence stigmatizing." [Levesque]

Organisations in the social economy have the particularity to participate and be deeply rooted in the territories in which they operate. Indeed, almost all the companies in the social economy located in a region or country are headquartered in the same region. They are therefore difficult to relocate and so provide stable emp- 
loyment in a region.

"The observation of the process of local development in the member countries of the OECD confirms that local development initiatives that have the best results in terms of economic growth, social progress and good governance are those which combine, often through local partnerships, all resources on the territory. Observation also shows that initiatives to promote employability, social inclusion, improving the quality of life and community development are often made by social enterprises through projects involving economic and social.dimensions" (OECD, 2007)

Indeed, in a first time, social enterprises have an advantage compared to conventional companies in terms of sustainability and environmental responsibility. Most of them work in the environmental sector. Social economy has developed numerous sustainable activities. The social and solidar economy enterprises for example, work in the sector of, recycling, green and renewable energy, local services, and ecological productions. In addition, some social enterprises are at the forefront: of green building, waste treatment, mobility, production and supply of alternative energy, sustainable food (SAW-B, 2007)

Social and solidar economy also offer advantages in the social field, because they have a role and a social purpose, and because it brings together all the enterprises and organizations which have, in the social economy, the aim to (re) enter the labor market and in society in general, people who are excluded (long-term unemployed, low-skilled, ex-prisoners or drug addicts ...).

But the sector of social economy is still too weak to influence and promote other modes of production, consumption and savings. For Michel Rocard, the means for social economy to strengthen is "to get out of its incredible shyness and show to everybody its many added values for citizens, governments, local authorities, but also companies, private or public. Its discretion is not called for in Europe, it holds most of the market share in key industrial sectors: agriculture, financial services and healthcare. At the same time, South America or Africa (for example), governments are turning to the solutions that it brings."

The question arising is: how can it play a more prominent role and change the scale to put people at the heart of what its projects focuse philosophically and statutorily?

\section{For an economy making sense, in an interconnected world}

We have seen, social and solidar economy is holding a non-violent project to transform the society, it is a practical utopia. Since the beginning these organizations show their dual capacity:

- Instrumental enterprise in the socio-economic field providing immediate responses 
(hic and nunc) to the difficulties caused by capitalism today.

- Institutions holding an alternative political project of emancipation (shared competence) and production of a social bond more respectful and more just as enshrined in its Charter.

Started in the XIXth Century to the micro enterprise level of the cooperative, this process of empowerment could not reach the macro level of the Republic of cooperative federations claimed by André Gide. Even if contemporary media are used to oppose worldwide solidarity to globalization of liberal economic paradigm , the intermixing of patterns of resistance, this world is too vast to be conquered by its values in a single bound.

So it is perhaps in the meso level of the territory, the region or the seat where you work and you live that the project of economic democracy has found the most appropriate space to spread.

As recalled by Michel Autes "there are three territory designs, and politics aim is to blend them together: the natural territory, ground and space to occupy, the political territory, result of struggles and conflicts that produce its borders and the symbolic territory, made of social objects expressing the relation of men to the previous two. We step from the first territory to the second by métonymisation and from the second to the third by metaphorization. " 12

This image of three levels constituting the territory, we may also, as Eric Dacheux did: use it to define the three pilars of a society

- The economic, as the way men are used to value their natural resources for their livelihood and exchange with neighboring territories (invention of money) or expropriation by conquest.

- The politic, as result of powership relations at a territorial level and in the relationship to other territories, holding of power and legitimate violence and expression of general interest in the democratic sense.

- The symbolic, as construction of legitimacy and meaning of two other levels (territorial conquests or great discoveries have always been accompanied by missions of evangelization, in the same way, Max Weber has demonstrated the link between the Protestant ethic and the Spirit of Capitalism) The history of economically developed western societies is the history of an unbalanced exchange supported at different times on the exploitation of the wealth of one part of society by another, then a part of the world by other.

What brought us the ecology is that these resources for which we are fighting for centuries are in limited quantities, as recalled Albert Jacquard: "Time is coming of a finite world."

What tries to make us understand social and solidar economy is that the logic is for the hygiene of mind like the ethics is for the hygiene of soul. The logic of our human behavior can not be limited only to the simplistic rationality of economic

${ }^{12}$ Autes M., op cit 
calculation (how to find rationality in the stock market booms or blatant waste of our consumers society, injustices or irreversible environmental damages?). If this utilitarian logic is not regulated, by an ethic of responsibility for the common good, can only lead to the ruin of a common humanity.

In a word, and without wishing to erect it as an exclusive alternative, a new messianism, social and solidar economy is undoubtedly an invitation to rebuild in our practices a sensible and therefore shared way to remake society/community. According to Jean François Drapery "The political and institutional maturity which finally reaches the SSE, as showing it today the creation of a Ministry for the SSE, provides to representative movements a new responsibility which they have already entered. 2012 is undoubtedly an important date in the history of SSE, for the first time, actors of this economy can expect the developpment of a real policy of social and solidar economy. "13 But as the author points out it in another article, if the solidar economy came spur social economy on its purposes, criticize its organization and its inclusion in the mainstream economy, the social economy is necessary to recall that the bases on its legal status is necessary to define its scope.

"Though insufficient, statutes cooperative mutualist and associatist have the first advantage of allowing the creation of groups with an economic activity in another way than bringing only equipment or capital. The fundamental point is that they actually permit the grouping, association, of persons. There is a close connection between the object of emancipation and the status group of persons, as there is a correspondence between the aim to remunerate capital and the status of capital societies. Even if these laws are imperfect, the worst that could happen would be their disappearing, which is not a fiction, looking to the evolution of the standards adopted by the European Community and by the main international bodies. Maintaining European statutes constituting the SSE is a major issue for the future. " Drapery JF]

The renewal of values of social economy is evidenced by the gradual recognition both at the national level (creation of a ministry and a bill project in 2013) than the European level (recent European Commission communication on social entrepreneurship, including initiative for social entrepreneurship in October 25, 2011)

"Social enterprise can certainly be an excellent program for change. for best results for the common good, to show that it is possible to act more responsible and fair, while remaining efficient on the markets and to become a real engine of growth in the EU. Europe must not only be part of these changes, it must also lead the way." José Manuel Barroso President of the European Commission.

"Initiative for Social Entrepreneurship engages national and regional governments and their partners to develop an enabling environment for social enterprises to intensify efforts at national and regional level, and do the best use of the Structural

\footnotetext{
${ }^{13}$ J F Draperie op cité
} 
Funds and other sources of funding available "Laslo Andor, EU Commissioner for Employment, Social Affairs and Inclusion.

At the same time some companies integrate social and environmental concerns into their strategies and management methods (Social Responsability). In a world every day more complex and uncertain, social and environmental seem access to the status of aim more than status of mean.

But this renewal, still only perceptible by an informed public, is not without raising some issues and debates upon its place and role in a difficult economic context marked in Europe by a structural crisis of regulated models of the previous century, a mutation of capitalism , and more generally big questions about our development model.

If we may, of course, enjoy this réintrication of economic social and politics in innovative ways at the territorial level, however, we should not give in too quickly to a naive hope of alternative way and "throw the baby out with the bath water" by burying the social gains from the virtuous period of welfare states as we are reminded by Philippe Frémeaux. ${ }^{14}$ Hybridization can also sometimes be the open door to the confusion.

Little known about a dozen years ago, the concepts of "social entrepreneurship" and of "social enterprise" are the subject of a spectacular increase both in the United States and Europe. These two concepts are however, considerably different on both sides of the Atlantic ocean. EMES, a european network of researchers, has been set up to study and conceptualize this phenomenon then already has affected much of Europe.

To speak quickly, we can say that sometimes (in the Anglo Saxon conception) it refers to a trend of designing social entrepreneurship as the act of a single individual, "social entrepreneur", which develops commercial activities with a social nature, and sometimes it clearly reflects the collective nature that defines the dynamics of social enterprises and is materialized in their statutes (cooperatives, associations, mutual societies and foundations) as in the concept of "social enterprise" in Europe where that term was born.

But the Anglo Saxon is gaining If this Anglo-Saxon influence is now much scope, it is probably because, in Europe, the field was ready. As already mentioned, the emergence of the concept of social enterprise since the early 2000s reflects new dynamics observed within the third sector. We see the emergence of organizations with new features (new legal forms, professionalization of factors of production, new types of activities, etc.).. Such changes concern in particular the relationship to the market.

Increasingly, governments "outsource" and develop quasi-markets for some services they provided before." (in France so called new public management)

\footnotetext{
${ }^{14}$ Frémeaux Philippe, La nouvelle alternative, Les petits matins, Alternative économique, 2011
} 
"To be efficient and adapted to the application, the system of bidding is more preferred. Thus, existing organizations are in a competition sometimes with profit enterprises for obtaining public funding or getting markets. They are therefore forced to develop management practices borrowed from the profit sector, and to face a greater economic risk. Their profitability is dependent on their ability to capture the market. This competitive regulation by the government has thus for result to accentuate the entrepreneurial aspect of associations and companies and to bring their management close to 'classic'.enterprises The emergence of new private solvent applications or their development (eg services for the elderly) also contribute to this entrepreneurial emphasis. " 15

The social economy is turning increasingly, driven by the political and economic context, to an entrepreneurial logic. The social economy is therefore involved itself in the emergence of a new conception of the third sector, more market- oriented, and provides a fertile ground for the spread of Anglo Saxon social entrepreneurship.

Must we worry about this movement? What are the issues?

This process often called "marchandization" does not escape to awareness of the actors and raises legitimate resistance and criticism of any management particularly in the area of social action. However what to do? The concept of social entrepreneurship in its various forms has undoubtedly helped to raise beyond his own area a wider audience for activities of social economy enterprises, expression of solidarity. Nevertheless is it only a fashion ? Social responsibility for some companies would it consist in repairing with the left hand the damage they produce with the right hand.

The EMES group's work has widely shown that what characterizes social enterprises in their underlying purpose is very different from a company that would do,parallel to its activity, some social action or from a company doing profit business with social needs.

Henri Desroche also demonstrated: Hope, in its messianism way, never reaches what it is waiting, and in the life of new ideas time of success can also be time of corruption.

But, within the actors in the social economy themselves, the risk may come from the doctrinal criticism (to hell the enterprise!) the outdated resistance (lost golden age of the welfare state!) and corporatist withdrawal, opposite of the values of solidarity and finaly generating the exclusion supposed to be struggled.

"If social entrepreneurship can play the role of mirror for the sector, it remains no less clearly that recognize, enforce and promote specificities of social economy seems now more than ever, a key issue. It is necessary not only to preserve but also to continue to disseminate the principles that consti-

\footnotetext{
${ }^{15}$ Dewandre Ariane, Entrepreneuriat social et économie sociale, SAW-B, Nov 2009.
} 
tute its spirit (collective action, democracy management, limited distribution of profits) and which are much wealth for a real economic alternative. "16

"There is no other world but different ways to live in this one." Latour 2002.

\section{Bibliographie}

- Autes M., Le sens du territoire, Recherches et Prévisions, No. 39, 1995.

- Artis Amélie, Demoustier Daniele et Puissant Emmanuelle, Le rôle de l'économie sociale et solidaire dans les territoires:, six études de cas comparées, RECMA No. 314.

- Braconnier,Patrice, Caire Gilles, Complexité, tension et richesse de la gouvernance des entreprises d'économie sociale.

- Bregeon Philippe "A quoi servent les professionnels de l'insertion?, l'Harmattan, 2008.

- Chanial Philippe et Laville Jean Louis , Economie sociale et solidaire : le modele français.

- Coutand Yves, Enfance des territoires et territoires de l'enfance, Géograhies de l'école rurale, (ss la dir ) de Yves Jean, Ophrys éditions, 2007.

- Dacheux Eric, Goujon Daniel, Principe d'économie solidaire, ellipses, 2011.

- Defourny Jacques, Nyssens Marthe, Approches européennes et américaines de l'entreprise sociale, une perspective comparative, colloque ADDES, nov 2010.

- De Nanteuil Mathieu, Economie plurielle et "réencastrement" :solution ou probleme face la marchandisation?, colloque EMES Bracelone 2008.

- Desroche Henri, Sociologie de l'espérance, Calman Levy, 1973.

- Dewandre Ariane, Entrepreneuriat social et économie sociale, SAW-B, Nov 2009.

- Draperie Jean François, Au bénéfice de la crise Pour un projet d'économie sociale et solidaire RECMA No. 330.

- Eme Bernard, Gouvernance territoriale et mouvements d'économie sociale, RECMA No. 296.

- Eme Bernard, Généalogie des régies de quartier, Ecologie et politique.

\footnotetext{
${ }^{16}$ Dewandre Ariane, op cité
} 
- Fleury:Cynthia "Les pathologies de la démocratie" Fayard biblio essais, 2005.

- Espagne François, Sur l'économie sociale et solidaire, RECMA No. 286.

- Frere Bruno, Le nouvel esprit solidaire, Desclée de Brouwer,2009.

- Frémeaux Philippe, La nouvelle alternative, Les petits matins, Alternative économique, 2011.

- Jantet Thierry: "L'économie sociale, une alternative au capitalisme", Economica, 2008 .

- Laville Jean Louis (ss la dir de), l'économie solidaire, Desclée de Brouwer, 1994.

- Laville Jean Louis, Agir a gauche, l'économie sociale et solidaire,Desclée de Brouwer, 2011.

- Laville Jean Louis, vers une économie sociale et solidaire, RECMA No. 281.

- Laville Jean-Louis, "Pour un dialogue Maussien", Revue du MAUSS, 2006/1 No. 27, p. 365-383.

- Lepretre Laura, L'économie sociale: l'alternative face a la crise, wp, Pour la solidarité, 2012.

- Levesque Benoît "les entreprises d'économie sociale plus porteuses d'innovation sociale que les autres", communication colloque ACFAS Mai 2001.

- Muller Pierre, "Les politiques publiques", PUF, 2000.

- Polianyi Karl : " la Grande Transformation ", Gallimard, 1983.

- La modernité de l'économie sociale, la revue de l'Economie sociale, Mars 1987.

- Panorama de l'économie sociale et solidaire en France et dans le régions, CNCRES 2010 et 2012. 